\section{Gravimetric Estimation of Silver as Silver Tetraisothiocyanatodianilinechromate(III)}

Gravimetrische Silberbestimmung als Silbertetraisothiocyanato-dianilinchromat(III)

Best. von Silber; Gravimetrie; als Silbertetraisothiocyanato-dianilinchromat(III)

\section{P. K. Mathur and L. N. Srivastava $†$}

Department of Chemistry, Lucknow University, Lucknow, India

Received April 14, 1972

A systematic investigation indicated that anilinium tetraisothiocyanatodianilinechromate(III) can be used as a selective reagent for the gravimetric estimation of silver. The reagent gives a red precipitate with silver nitrate solution, insoluble in common organic solvents and easy to wash. The exceedingly high molecular weight of the precipitated compound rendered it possible to estimate silver in minute quantities. The ratio of silver and the precipitated compound is 1:5.35. Repeated attempts were made to confirm the results of this new technique through a number of experiments involving determination of silver in various silver solutions of varying strengths.

\section{Experimental}

Reagent Solution. (Aniline) $\left.\mathrm{H}\left[\mathrm{Cr}(\mathrm{SCN})_{4} \text { (aniline) }\right)_{2}\right]$ was prepared by the method of Ganescu [1]. A saturated solution of the reagent in alcohol was used for all precipitations.

Procedure. Add freshly prepared saturated solution of the reagent in alcohol to the silver solution $(\mathrm{pH} \approx 2)$ in slight excess to precipitate out red coloured $\left.\mathrm{Ag}\left[\mathrm{Cr}(\mathrm{SCN})_{4} \text { (aniline }\right)_{2}\right]$. Thereafter, keep in an ice-bath for 30 min with stirring, filter off on a weighed sintered crucible, wash with cold water, alcohol then ether and dry at $110-120^{\circ} \mathrm{C}$.

Table 1. Separation of silver from foreign ions. Ag taken $19.12 \mathrm{mg}$

\begin{tabular}{|c|c|c|c|c|c|}
\hline \multirow{2}{*}{$\begin{array}{l}\text { Expt. } \\
\text { No. }\end{array}$} & \multicolumn{2}{|c|}{ Metal ions } & \multirow{2}{*}{$\begin{array}{l}\text { Wt. of } \\
\text { ppt. mg }\end{array}$} & \multirow{2}{*}{$\begin{array}{l}\mathrm{Ag} \text { found } \\
\mathrm{mg}\end{array}$} & \multirow{2}{*}{$\begin{array}{l}\text { Error } \\
\text { mg }\end{array}$} \\
\hline & added & $\mathrm{mg}$ & & & \\
\hline 1 & $\mathrm{Li}^{+}$ & 18.71 & 102.4 & 19.13 & +0.01 \\
\hline 2 & $\mathrm{Be}^{2+}$ & 14.72 & 103.0 & 19.25 & +0.13 \\
\hline 3 & $\mathrm{Mg}^{2+}$ & 15.36 & 103.2 & 19.28 & +0.16 \\
\hline 4 & $\mathrm{Zn}^{2+}$ & 23.41 & 102.4 & 19.13 & +0.01 \\
\hline 5 & $\mathrm{Cd}^{2+}$ & 18.88 & 103.2 & 19.28 & +0.16 \\
\hline 6 & $\mathrm{Sr}^{2+}$ & 19.44 & 103.6 & 19.25 & +0.13 \\
\hline 7 & $\mathrm{Al}^{3+}$ & 20.46 & 103.4 & 19.32 & +0.20 \\
\hline 8 & $\mathrm{~Pb}^{2+}$ & 22.52 & 102.4 & 19.13 & +0.01 \\
\hline
\end{tabular}

Amounts of $19-32 \mathrm{mg}$ of $\mathrm{Ag}$ (corresponding to a weight of precipitate of $102-171 \mathrm{mg}$ ) have been successfully determined with errors of -0.02 to $+0.09 \mathrm{mg}$. Many cations do not interfere, e. g., $\mathrm{Li}^{+}$, $\mathrm{Be}^{2+}, \mathrm{Mg}^{2+}, \mathrm{Zn}^{2+}, \mathrm{Cd}^{2+}, \mathrm{Sr}^{2+}, \mathrm{Al}^{3+}$ and $\mathrm{Pb}^{2+}$. Results are shown in Table 1. However, the estimation cannot be carried out in presence of $\mathrm{Cl}^{-}, \mathrm{Br}^{-}, \mathrm{I}^{-}$and $\mathrm{SCN}^{-}$ ions. These ions precipitate with silver ions.

In the analysis of $\left.\mathrm{Ag}\left[\mathrm{Cr}(\mathrm{SCN})_{4} \text { (aniline) }\right)_{2}\right]$, silver was estimated as $\mathrm{AgCl}$ volumetrically, chromium also volumetrically and nitrogen by Kjeldahl method. The following values have been found: $\mathrm{Ag}, 18.53$ (18.67); Cr, 8.89 (9.00); N, 14.41 (14.53); calculated values in parenthesis.

Acknowledgements. Our sincere thanks are due to Prof. Ram Gopal, Head of the Chemistry Department, Lucknow University, for providing laboratory facilities and encouragement. One of the authors (P.K.M.) is grateful to the C.S.I.R. (New Delhi, India) for the award of a Junior Research Fellowship.

\section{Reference}

1. Ganescu, I.: Chem. Abstr. 68, 45740m (1968).

P. K. Mathur

Department of Chemistry

Lucknow University

Lucknow, India

\section{Massenspektroskopische Fragmentierung der Trimethylsilyl-Derivate von 6-Sulfonsäure- und Phosphorsäure- substituierten Pteridinen}

Mass Spectral Fragmentation of Trimethylsilyl Derivatives of 6-Sulphonic and Phosphoric Acid Substituted Pteridines

Untersuchung von Pteridinen; Massenspektrometrie; Fragmentierung der Trimethylsilylderivate von 6-Sulfon- und Phosphorsäure-subst. Pteridinen

J. W. Serum

Dept. of Chemistry, Cornell Univ., Ithica, N. Y., U.S.A.

P. Haug

Geochem. Inst. der Univ. Göttingen

T. Urushibara und H. S. Forrest

Dept. of Zoology, Univ. of Texas, Austin, Tex., U.S.A.

Eingegangen am 16. Juni 1972

Wir haben die Massenspektren von 4 substituierten Pteridinen mit einer Säurefunktion in 6-Stellung bzw. in 6-Stellung in einer Seitenkette untersucht. Von diesen Verbindungen wird angenommen, daß sie 